\title{
ON THE RESURRECTION OF THE BODY: DISCUSSION WITH TRENTON MERRICKS
}

\author{
PETER DRUM \\ Australian Catholic University
}

\begin{abstract}
In a recent discussion, Trenton Merricks concludes that we cannot understand how God might miraculously bring it about that there will be the Resurrection of the Body. It is contended to the contrary, that it is not utterly mysterious how God might give us our bodies back.
\end{abstract}

\section{THE DOCTRINE}

The Christian doctrine of the Resurrection of the Body is explained by Trenton Merricks as follows: 'we shall not spend eternity as mere spirits or as disembodied souls. Instead, we shall have hands and feet and size and shape. For, we shall have bodies. And not just any bodies. Each of us will have the very same body that he or she had in this life, although the body will be "glorified". Each of us can have the same body because, at some point in the future, all those bodies that have died will rise again to new life. That is, dead bodies will be resurrected.' ${ }^{1}$ However, he points out that this raises the question: 'how could a body that has passed out of existence - perhaps as a result of decay or cremation - come back into existence on the Day of the Resurrection?'2

\footnotetext{
1 'The Resurrection of the Body', Chapter 21 in Thomas P. Flint and Michael C. Rea, The Oxford Handbook of Philosophical Theology, Oxford: Oxford University Press, 2009, p. 476. ${ }^{2}$ Ibid.
} 


\section{THE DIFFICULTIES}

In answer to it, Merricks notes that ' $[o] v e r$ the centuries, the most common account amongst Christian philosophers and theologians, an account that was also countenanced by Islamic and Jewish thinkers, has been this: on the Last Day, God will gather up the very small bits that composed a body at death and will "reassemble" them, which will thereby bring the body that died back into existence ... ${ }^{3}$ Yet, '[o]ne potential problem with this account is that even a body's smallest parts might themselves go out of existence [e.g., matter might be converted to energy].4 And, '[a]nother objection to resurrection as reassembly trades on the many ways in which the small parts of one body can end up as parts of another body [e.g., most starkly in the instance of cannibalism]. ${ }^{5}$ Furthermore, 'our bodies are constantly changing with respect to the very small bits that compose them ... Therefore, a body's identity from one moment to the next is not a matter of having exactly the same very small parts.' ${ }^{3}$ Thus, it seems that 'nothing could account for or ground identity across (at least some) resurrection-induced temporal gaps.' This notwithstanding, Merricks contends that believers 'can simply conclude that there will be something in virtue of which each resurrection body will be identical with a body had in this life, something that will ground or account for that identity. Crucially, they can conclude this even given their inability to discover that ground, an inability evidenced by the failure of proposed accounts such as reassembly. After all, no one should presume to know exactly how God pulls off any miracle, including the resurrection of the body.' However, this will not do. For, it is incumbent upon anyone defending any scriptural doctrine to show that it is not absurd, 'lest Holy Scripture be exposed to the ridicule of unbelievers, and obstacles be placed to their believing.' So, can this be achieved?

\footnotetext{
${ }^{3}$ Ibid., p. 478.

${ }^{4}$ Ibid.

${ }^{5}$ Ibid.

${ }^{6}$ Ibid., pp. 478-9.

${ }^{7}$ Ibid., p. 480.

${ }^{8}$ Ibid.

${ }^{9}$ St Thomas Aquinas, Summa Theologica, 2a2ae,. 33, 4 ad 2.
} 


\section{BODILY SAMENESS}

In order to answer this question, note that Merricks says that '[e]ach of us will have the very same body that he or she had in this life, although the body will be "glorified"'. And, since this flesh, and this blood, and this bone, cease to exist in the dissolution of death, the idea of getting our bodies back does not seem to make much sense. However, this is not entirely correct. For, although after dissolution it might be impossible for me to get the same body back numerically, I could get it back otherwise, since there is more than one meaning of sameness: 'things are said to be the same ... whose matter is one either in kind or in number ... [and it is also the case that] ... those whose essence [form] is one, are said to be the same. ${ }^{10}$ Therefore, after its dissolution, my resurrected body would be the 'same' body that I had earlier if it had the same essential character. For, it then it would have exactly the same material and formal qualities it had earlier, perfected and glorified.

Yet, this does not appear to do complete justice to the doctrine. For, by it, it seems that I am meant to get this very same body back, which means also numerical sameness. So, can this be retained? Not, it would seem, if we subscribe to Dean W. Zimmerman's argument from fission; viz. that, "just before it completely loses its living form ... [God enables] ... each particle to divide - or at least to be immanent-causally responsible for two resulting particle-stages. One of the resulting particle-stages is right here, where the old one was; another is either in heaven now (for immediate resurrectionists), or somewhere in the far future. ${ }^{11}$ For, then the resultant can hardly be said to be me, but rather me divided. However, the suggestion that somehow or other there must be two 'me's for me to get my body back at the resurrection is not altogether unpromising. For, for the time that I am alive, my body is my physical form. Yet, the body of the Risen Christ is meant to be imperishable, glorious, powerful, and spiritual in nature ${ }^{12}$, and 'whoever has a glorified body has it in his power

${ }^{10}$ Aristotle, Metaphysics, V, 9.

11 'The Compatibility of Materialism and Survival: "The Falling Elevator" Model', Faith and Philosophy, vol. 16, no. 2, April 1999, p. 206. (Note that Timothy O'Connor and Jonathan D. Jacobs have recently advanced an intriguing version of this argument. [See 'Emergent Individuals and the Resurrection', European Journal for Philosophy of Religion, vol. 2, no. 2, 2010.] However, for the same reason it is also unacceptable.)

${ }^{12}$ St Paul, 1 Corinthians, 15:42-44. 
to be seen when he so wishes, and not to be seen when he does not wish it [and pass through walls ${ }^{13}$, and so on]. ${ }^{14}$ So, might it not be the case that, when I die, my body is spiritualized; so that what is now my body ceases to be my body at all? That is, as a snake sheds its skin, my body-asbody is then transformed into my body-as-soul, and leaves its former self behind. For example, from physical element-of-my-body $\mathrm{x}$ is actuated metaphysical element-of-my-body $\mathrm{x}$; so physical element $\mathrm{x}$ is reduced to being merely a random element, and my continuity as a body is in terms of metaphysical element $\mathrm{x} .{ }^{15}$ For, a body is a unity, and this unity has now assumed the form of being a unity of metaphysical parts. This is arguably why 'ancient corpses suddenly become ashes in the grave' ${ }^{16}$, for they are no longer really 'bodies' at all. Thus, just as 'a dead man is a man in only in name ${ }^{17}$, so too would a dead body be a body in name only. ${ }^{18}$ (This is because its unity - for as long as it lasts - is now merely accidental.) Consequently, although '[s]omeone may ask, "How are dead people raised and what sort of body do they have when they come back?" They are stupid questions. Whatever you sow in the ground ... is not what is going to come; you sow a bare grain, say of wheat or something like that, and then God gives it the sort of body that he has chosen ... It is the same with the resurrection of the dead: the thing that is sown is perishable but what is raised is imperishable ... glorious ...'19

\section{CONCLUSION}

It need not be relegated to the realms of absolute mystery how God might give us our bodies back in the end. For, despite the temporal gap between the dissolution of my material body and the Day of the Resurrection, there is understandably a way for my disembodied soul then to be allocated exactly the same body I had in death; viz. through bodily transformation.

\footnotetext{
${ }^{13}$ John, 20:19.

${ }^{14}$ St Thomas Aquinas, Summa Theologica, 3a. 54, 1 ad 2.

15 There is nothing esoteric about this: evidently there are emergent metaphysical powers in things - e.g., life in seeds - so why not also emergent metaphysical properties?

${ }^{16}$ Aristotle, Meteorology, IV, 12.

${ }^{17}$ Aristotle, Meteorology, loc. cit.

${ }^{18}$ Needless to say, the notion of a spiritual body is itself conceptually opaque.

${ }^{19}$ St Paul, 1 Corinthians, 15: 35-44.
} 